\title{
Automatic milking systems in the Protected Designation of Origin Montasio cheese production chain: Effects on milk and cheese quality
}

\author{
N. Innocente ${ }^{1}$ and M. Biasutti \\ Department of Food Science, University of Udine, via Sondrio 2/A, 33100 Udine, Italy
}

\begin{abstract}
Montasio cheese is a typical Italian semi-hard, semi-cooked cheese produced in northeastern Italy from unpasteurized (raw or thermised) cow milk. The Protected Designation of Origin label regulations for Montasio cheese require that local milk be used from twice-daily milking. The number of farms milking with automatic milking systems (AMS) has increased rapidly in the last few years in the Montasio production area. The objective of this study was to evaluate the effects of a variation in milking frequency, associated with the adoption of an automatic milking system, on milk quality and on the specific characteristics of Montasio cheese. Fourteen farms were chosen, all located in the Montasio production area, with an average herd size of 60 (Simmental, Holstein-Friesian, and Brown Swiss breeds). In 7 experimental farms, the cows were milked 3 times per day with an AMS, whereas in the other 7 control farms, cows were milked twice daily in conventional milking parlors (CMP). The study showed that the main components, the hygienic quality, and the cheese-making features of milk were not affected by the milking system adopted. In fact, the control and experimental milks did not reveal a statistically significant difference in fat, protein, and lactose contents; in the casein index; or in the HPLC profiles of casein and whey protein fractions. Milk from farms that used an AMS always showed somatic cell counts and total bacterial counts below the legal limits imposed by European Union regulations for raw milk. Finally, bulk milk clotting characteristics (clotting time, curd firmness, and time to curd firmness of $20 \mathrm{~mm}$ ) did not differ between milk from AMS and milk from CMP. Montasio cheese was made from milk collected from the 2 groups of farms milking either with AMS or with CMP. Three different cheese-making trials were performed during the year at different times. As expected, considering the results of the milk analysis, the moisture, fat, and protein contents of the experimental and control
\end{abstract}

Received March 7, 2012.

Accepted October 29, 2012.

${ }^{1}$ Corresponding author: Nadia.Innocente@uniud.it cheeses were comparable. The milking system was not seen to significantly affect the biochemical processes associated with ripening. In fact, all cheeses showed a normal proteolysis trend and a characteristic volatile compound profile during aging. Therefore, the milking system does not appear to modify the distinctive characteristics of this cheese that remain dependent on the area and methodology of production.

Key words: automatic milking, conventional milking parlor, milk, cheese

\section{INTRODUCTION}

In dairy cattle breeding, there is increasing worldwide interest in the adoption of automatic milking systems (AMS), mainly because these systems represent an opportunity to relieve the farmer from the labor-intensive routine of the conventional milking parlor (CMP; Abeni et al., 2003). Indeed, in AMS, human involvement is not required during milking and the machine prepares the cow for milking independently according to settings that are preprogrammed (Salovou et al., 2005). A further advantage is that the system includes voluntary visits to the unit for milking, which may occur more than twice daily. A systematic increase in milking frequency is known to determine an increase in milk production for multiparous cows (Ouweltjes, 1998; Abeni et al., 2008; Svennersten-Sjaunja and Pettersson, 2008). In fact, abundant evidence exists that the rate of milk secretion is directly correlated with milking frequency as a result of the mechanisms related to the local control of milk secretion (Knight et al., 1998). Milking 3 times instead of twice daily has been shown to increase milk yield by between 6 and $28 \%$, depending on parity (Klei et al., 1997; Løvendahl and Chagunda, 2011). On the other hand, it has been reported that AMS could negatively affect some milk quality features, including total bacterial plate count, SCC, FFA, and perhaps, protein and fat content (Klungel et al., 2000).

In actual fact, the effect of the introduction of AMS on the composition and hygienic quality of milk is a matter of debate: the effects of AMS on udder health and milk quality have been evaluated in several experiments, but the results are often contradictory. Accord- 
ing to several studies, total bacteria and SCC rise after the introduction of this milking system due to irregular milking intervals that could have negative effects on udder health (Kaartinen et al., 1990; Rasmussen et al., 2002; Nielsen et al., 2005). However, cases exist in which the authors claim that there was no effect on $\mathrm{SCC}$, or even, in some cases, an improvement (Klungel et al., 2000; Berglund et al., 2002; Salovou et al., 2005). Recently, Mollenhorst et al. (2011) showed that the effect of milking interval on SCC, although significant in itself, was marginal when corrected for other variables, such as lactation stage and parity. Regarding the effect of milking frequency on milk composition, different studies have shown that milk fat and protein percentages are significantly lower in herds milking 3 times per day than in those milking twice per day (Klei et al., 1997; Friggens and Rasmussen, 2001; Smith et al., 2002). However, Allen at al. (1986) reported only a slightly lower milk fat percentage from cows milked 3 times compared with cows milked twice per day. Contrarily, Amos et al. (1985) and DePeters et al. (1985) indicated that milk composition is not affected by milking frequency at all. Løvendahl and Chagunda (2011) explained that the variance of the relationships between milking frequency, milk yield, and milk composition in terms of fat and protein content are partially determined by the characteristic changes in the individual cow during lactation and that they may also be affected by breed of cow.

Moreover, it is important to consider that each milk quality feature plays a different role when the end use is taken into account. So, if the milk is used in cheese production, it is necessary to better understand the real effect of AMS on features that may affect the cheesemaking process (Abeni et al., 2003). It is known that changes in the composition of milk components can influence the quality and yield of cheese (Sapru et al., 1997). In particular, casein percentage and quality affect clotting properties and, as a result, the efficiency of the transformation process and final product quality. The renneting features of caseins may be altered by the action of endogenous proteases that can be present in milk. The most important endogenous protease is plasmin, which derives from the activation of its inactive form, plasminogen, through the work of plasminogen activators (PA). The existence of a relationship between plasmin activity and milking frequency can be discerned from the works of Stelwagen et al. (1994) and Sorensen et al. (2001): by changing from 1 to 2 and from 2 to 3 milkings per day, the time available for plasminogen to be converted to plasmin was reduced. These results suggest that AMS could improve milk casein content through increased milking frequency (Abeni et al., 2003, 2008).
Regarding the effect of milking frequency on milk fat characteristics, Klei et al. (1997) reported a greater FFA content in milk when cows were milked three times rather than twice daily. An increase in FFA content, due to reduced milking intervals, was confirmed by Klungel et al. (2000), who also provided evidence that when milking occurred with an AMS, the increase was greater than that in milk from a third daily milking in a CMP. This is important because, according to Downey (1980), increased FFA content can cause flavor defects in dairy products.

However, no studies are available that evaluate the direct influence of AMS on the final characteristics of the cheeses. This aspect is of even greater interest when you consider Protected Designation of Origin (PDO) cheeses, because these types of food must show that production is based on "authentic and unvarying local methods" and "tradition" as quoted in European Union Regulation 510/06 (Council Regulation EC No. 510, 2006; European Commission, 2006). This designation implies that the cheeses have distinctive characteristics that are associated with traditional production methods (milk production, manufacturing techniques, and the ripening process), thus guaranteeing the consumer quality that lasts over time.

Montasio cheese is a typical Italian semi-hard, semicooked cheese produced in northeastern Italy from unpasteurized (raw or thermised) cow milk. The PDO label regulations for Montasio cheese require the use of local milk from twice-daily milkings. The number of farms milking with AMS has increased rapidly in the last few years, also in the Montasio production area. It is, therefore, necessary to evaluate the effect of this milking system on the typical characteristics of this cheese. The aim of this study was to evaluate the effects of variation in milking frequency, associated with the adoption of an automatic milking system, on the hygienic quality and physicochemical characteristics of milk used in Montasio cheese production and on the chemical composition, proteolysis, volatile fraction profile, and sensory characteristics of the final product.

\section{MATERIALS AND METHODS}

\section{Dairy Cows and Milking}

Fourteen farms located in the Montasio cheese production area in northeastern Italy took part in this study. Table 1 shows general information about individual farms. The farms keep herds with an average of 60 Simmental, Holstein-Friesian, or Brown Swiss cows. The animals were fed $67 \%$ silo corn, $18 \%$ hay, and $15 \%$ concentrate feed in accordance with the PDO regulations for Montasio cheese. 
Table 1. General information about individual farms

\begin{tabular}{|c|c|c|c|}
\hline Farm & Milking machine & $\begin{array}{c}\text { No. of } \\
\text { animals }\end{array}$ & Breed \\
\hline 1 & Lely Astronaut ${ }^{1}$ & 60 & $100 \%$ Holstein-Friesian \\
\hline 2 & Lely Astronaut & 65 & $\begin{array}{l}60 \% \text { Holstein-Friesian } \\
30 \% \text { Simmental } \\
10 \% \text { Brown Swiss }\end{array}$ \\
\hline 3 & WestfaliaSurge $^{2}$ & 58 & $\begin{array}{l}90 \% \text { Brown Swiss } \\
10 \% \text { Holstein-Friesian }\end{array}$ \\
\hline 4 & VMS, DeLaval $^{3}$ & 56 & $100 \%$ Holstein-Friesian \\
\hline 5 & Lely Astronaut & 67 & $\begin{array}{l}60 \% \text { Holstein-Friesian } \\
20 \% \text { Simmental } \\
20 \% \text { Brown Swiss }\end{array}$ \\
\hline 6 & WestfaliaSurge & 60 & $100 \%$ Simmental \\
\hline 7 & VMS, DeLaval & 59 & $\begin{array}{l}70 \% \text { Holstein-Friesian } \\
10 \% \text { Simmental } \\
20 \% \text { Brown Swiss }\end{array}$ \\
\hline 8 & Conventional milking parlor & 66 & $\begin{array}{l}80 \% \text { Simmental } \\
20 \% \text { Brown Swiss }\end{array}$ \\
\hline 9 & Conventional milking parlor & 54 & $100 \%$ Holstein-Friesian \\
\hline 10 & Conventional milking parlor & 60 & $\begin{array}{l}60 \% \text { Holstein-Friesian } \\
20 \% \text { Simmental } \\
20 \% \text { Brown Swiss }\end{array}$ \\
\hline 11 & Conventional milking parlor & 68 & $\begin{array}{l}50 \% \text { Holstein-Friesian } \\
30 \% \text { Simmental } \\
20 \% \text { Brown Swiss }\end{array}$ \\
\hline 12 & Conventional milking parlor & 55 & $\begin{array}{l}70 \% \text { Holstein-Friesian } \\
30 \% \text { Brown Swiss }\end{array}$ \\
\hline 13 & Conventional milking parlor & 57 & $\begin{array}{l}90 \% \text { Holstein-Friesian } \\
10 \% \text { Brown Swiss }\end{array}$ \\
\hline 14 & Conventional milking parlor & 60 & $\begin{array}{l}50 \% \text { Simmental } \\
50 \% \text { Brown Swiss }\end{array}$ \\
\hline
\end{tabular}

${ }^{1}$ Lely, Bain-de-Bretagne, France.

${ }^{2}$ GEA Farm Technologies GmbH, Bönen, Germany.

${ }^{3}$ DeLaval Group, Tumba, Sweden.

In 7 experimental farms, the cows were milked with an AMS (VMS, DeLaval Group, Tumba, Sweden; WestfaliaSurge, GEA Farm Technologies GmbH, Bönen, Germany; Astronaut robot, Lely, Bain-de-Bretagne, France). The mean milking frequency was 3 times per day. In the other 7 control farms, cows were milked with traditional systems in CMP. In this case, cows were milked twice per day.

\section{Cheese Making}

On 3 separate occasions during a 12 -mo period a total of $10,000 \mathrm{~kg}$ of bulk milk was collected from the experimental farms and $100 \mathrm{~kg}$ from the control farms. The experimental and the control milks were put in 2 separate vats for cheese making. In this way, 3 different cheese-making trials were carried out for AMS milk and for CMP milk. All cheese makings were carried out in the same dairy following the traditional production techniques laid down in the PDO regulations for Montasio cheese (Commission Regulation EC no. 1107; European Commission, 1996). The raw unpasteurized milk, collected every $24 \mathrm{~h}$, was heated to 32 to $34^{\circ} \mathrm{C}$ and inoculated with $1 \%$ of direct-to-vat powder commer- cial starter culture (Mofin Alce Group, Novara, Italy). Liquid calf rennet with high chymosin content $(75 \%$ chymosin and $25 \%$ pepsin) was used to give coagulation in 15 to $20 \mathrm{~min}$. The coagulum was cut into hazelnutsized pieces and then cooked at 45 to $46^{\circ} \mathrm{C}$ for $20 \mathrm{~min}$. The curd was then removed from the heat source and continuously stirred to obtain a greater syneresis of the whey. After about 20 to $30 \mathrm{~min}$, the curd was extracted from the vat using an automatic system that pumps the curd and whey onto a horizontal bench in which the molds are placed. The curd was packed into 7 - to $8-\mathrm{kg}$ circular molds (diameter of 30 to $35 \mathrm{~cm}$ and height of 8 $\mathrm{cm}$ ) that were then placed in a pneumatic cheese press and pressed for a total of $24 \mathrm{~h}$ at an average of 400 $\mathrm{kPa}$. After salting in brine (16 to $18 \% \mathrm{wt} / \mathrm{wt}$ of sodium chloride) for $24 \mathrm{~h}$ at $11^{\circ} \mathrm{C}$, the cheese was ripened for 12 mo in a ripening room at a temperature of $8^{\circ} \mathrm{C}$ and a relative humidity of $80 \%$.

\section{Collection and Analysis of Milk Samples}

Somatic cell counts, total microbial count, and freezing point were determined on bulk milk from each of the farms considered in this study. Milk samples were 
analyzed for SCC (cells $/ \mathrm{mL}$ ) by a fluoro-opto-electronic method using a Fossomatic 5000 (Foss Electric A/S, Hillerød, Denmark) and for total bacteria count (TBC; $\mathrm{cfu} / \mathrm{mL}$ ) by automated fluorescence microscopy (BactoScan 8000; Foss Electric A/S). The freezing point $\left({ }^{\circ} \mathrm{C}\right)$ was determined according to the Estonian Center for Standardization (EVS-EN ISO, 2002; 5764) with a thermistor milk cryoscope (model 4DII; Advanced Instruments Inc., Norwood, MA).

For the chemical and rheological analyses, milk samples were collected from each vat of cheese. Experimental and control milk samples were taken directly from the respective cheese vat once the milk had reached a temperature of $33^{\circ} \mathrm{C}$ and before the addition of the starter culture.

The determination of the fat content in the milk was performed following the Röse-Gottlieb method (IDF, 1996). Total nitrogen (TN) and noncasein nitrogen were determined according to the Kjeldahl method and the casein nitrogen was calculated as the difference between TN and noncasein nitrogen (IDF 1964a; Barbano et al., 1990). Results are expressed on an equivalent protein basis (total nitrogen $\times 6.38$ ). The casein index is found by calculating the percentage ratio between the casein nitrogen and TN. The whey protein and the casein profiles of milk were evaluated by reversed-phase HPLC. To separate the whey proteins, milk samples were prepared following the method proposed by De Noni et al. (2007), whereas to obtain the casein profiles, milk samples were prepared following the method proposed by Bobe et al. (1998). Lactose content was determined by HPLC following the method proposed by Jeon et al. (1984).

Milk rheological characteristics were analyzed by a Formagraph instrument (Formagraph 11700; Foss Electric A/S), thus obtaining the following parameters: clotting time $(r, \mathrm{~min})$, the time from the addition of rennet to the beginning of coagulation; curd firmness $\left(\boldsymbol{a}_{30}, \mathrm{~mm}\right)$, measured $30 \mathrm{~min}$ after the addition of rennet; and the time to curd firmness of $20 \mathrm{~mm}\left(\boldsymbol{k}_{20}\right.$, min; McMahon and Brown, 1982).

\section{Analysis of Cheese During Ripening}

About 130 cheeses were obtained from a 10,000 kg vat and all these cheeses were cured in the same aging room for $365 \mathrm{~d}$. Cheese samples were taken at different stages of the ripening process (at 60,90,170, 300, and $365 \mathrm{~d}$ ). To obtain a representative sample of cheese, at each sampling time, a whole segment was cut from the center to the edge of the cheese, the rind $(2 \mathrm{~cm})$ was removed, and the sample (about $500 \mathrm{~g}$ ) was finely grated.

The following compositional analyses were performed on each cheese sample: fat (gravimetric Schmid-Bon-
dzynski-Ratzlaff method; IDF, 1986), protein (macroKjeldahl; IDF, 1964b), and moisture (oven drying at $102^{\circ} \mathrm{C}$; IDF, 1982). The water-soluble nitrogen (SN)/ TN was used as an index of proteolysis (Innocente, 1997). The water-soluble extract was prepared by grinding $4 \mathrm{~g}$ of grated cheese in a mortar with water at $50^{\circ} \mathrm{C}$ and diluting to $100 \mathrm{~mL}$. The homogenate was filtered and analyzed for nitrogen using the Kjeldahl method. Total $\mathrm{N}$ was determined by placing $0.5 \mathrm{~g}$ of grated cheese directly in a Kjeldahl digestion flask. Volatile compounds were determined using the headspace solidphase microextraction (HS-SPME) method coupled with GC-MS detection (Biasutti and Innocente, 2006).

Sensory analysis was carried out by a panel of 8 judges trained according to the methodological approach proposed by 2 European guides for hard and semi-hard cheeses (Lavanchy et al., 1993; Bérodier et al., 1997). The training was been completed within 2 mo (about $14 \mathrm{~h}$ of activity for each judge). Judges were trained to quantify the basic tastes (salt, acid, bitter, and sweet), the texture parameters (elasticity, firmness, deformability, friability, and adhesivity), and the intensity of aroma or smell of cheeses on a 1 to 7 scale, where 1 represented absence and 7 represent maximum perception of the attribute under evaluation. The standards used to anchor panelists were prepared according to the instructions of Bérodier et al. (1997) for the texture parameters, and of Lavanchy et al. (1993) for the aroma and taste descriptors.

The mean and the standard deviation of sensory descriptors were calculated from the scorecard filled by the judges for each cheese sample. The data so obtained were elaborated using a spider-plot representation were each axis reports the mean of a specific parameter. The typical profile is then obtained linking each point on the axis.

\section{Statistical Analysis}

Three different cheesemaking batches were studied for experimental and control milk samples and each time all the analyses were carried out 3 times on the milk and on the cheese. The data shown are, therefore, the averages of the 9 values obtained.

One-way ANOVA (F-test) and Student's $t$ and Tukey honestly significant difference tests were used to compare the mean values. The differences were considered statistically significant for $P \leq 0.05$. The statistical analysis was performed using Statistical Discovery JMP 3.0 for Windows (SAS Institute Inc., Cary, NC).

\section{RESULTS AND DISCUSSION}

\section{Hygienic Milk Quality}

Milk SCC and TBC are frequently used markers for both udder health and milk quality (O'Brien et al., 
2001). The consequences of high values of these markers on the technological properties of milk and on the quality of milk products are extensively reported in the literature. It has been shown that an increase in milk SCC can cause an increase in the amount of proteolytic activity and can reduce the yield and quality of cheese (Albenzio et al., 2004). Kelly and McSweeney (2002) found that an elevated SCC can lead to the following effects: an alteration of protein fraction distribution; a decrease in casein and lactose levels in milk; an increase in rennet clotting time, cheese moisture, and in the loss of fat and proteins in whey; and a reduction in curd firmness and cheese yield. The TBC of milk is an indicator of milking hygiene and in the production of raw milk cheeses, such as Montasio cheese, it is particularly important for the milk to have a low TBC. Furthermore, gram-negative proteolytic psychrotrophic bacteria might cause spoilage of milk and milk products, due to their ability to produce thermostable proteases that hydrolyze casein and decrease the yield and sensory quality of dairy products (Sørhaug and Stepaniak, 1997). Table 2 reports the SCC (log cells $/ \mathrm{mL}$ ) and the TBC (log cfu/mL) of the AMS milk and CMP milk. It can be seen that no statistically significant differences (Student's $t$-test, $P \leq 0.05$ ) existed between the 2 types of milk compared. Moreover, on all the farms included in the study, independent of the milking system, milk always showed a SCC and a TBC far lower than 400,000 and $100,000 \mathrm{cfu} / \mathrm{mL}$, respectively, which are the legal limits imposed by the EC regulation for raw milk (Regulation EC No. 853/2004; European Commission, 2004). It can, therefore, be affirmed that in all the observed conditions, the AMS does not determine the presence in bulk milk of a SCC or a TBC that might compromise the production or the quality of Montasio cheese. Where hygiene is concerned, the results reported by different authors are often contradictory. In particular, according to several studies, variation in milking frequency, associated with the adoption of an AMS, may in itself be problematic, as the teats do not have enough time to recover, which may increase ud-

Table 2. The SCC (log cells $/ \mathrm{mL}$ ) and the total bacteria count (log $\mathrm{cfu} / \mathrm{mL}$ ) in automatic milking system (AMS) milk and in conventional milking parlor (CMP) milk ${ }^{1}$

\begin{tabular}{lcc}
\hline & \multicolumn{2}{c}{ Milking system } \\
\cline { 2 - 3 } Item & AMS & CMP \\
\hline SCC (log cells/mL) & $5.29 \pm 0.09^{\mathrm{a}}$ & $5.18 \pm 0.10^{\mathrm{a}}$ \\
Total bacterial count $(\log \mathrm{cfu} / \mathrm{mL})$ & $4.44 \pm 0.21^{\mathrm{a}}$ & $4.38 \pm 0.19^{\mathrm{a}}$ \\
\hline
\end{tabular}

${ }^{\mathrm{a}}$ Different superscript letters within a row refer to statistically significant differences (Student's $t$-test, $P \leq 0.05$ ).

${ }^{1}$ Values are the arithmetic means $( \pm \mathrm{SD})$ of 9 values obtained at 3 different times during the year. der health problems in the long run (Neijenhuis et al., 2001; Nielsen et al., 2005). When milking intervals were decreased to below $6 \mathrm{~h}$, SCC increased in milk from healthy as well as unhealthy quarters. In other studies, however, no effect of milking 2 or 3 times per day on SCC could be found, in agreement with our SCC data (Berglund et al., 2002; Österman et al., 2005). Concerning the TBC, divergent opinions are again found. Klungel et al. (2000) assert that although an AMS is in use for $24 \mathrm{~h}$ per day, the system does not actually milk cows $24 \mathrm{~h}$ per day. Hence, milk remains in the system for some time, which may enhance bacterial growth. In addition, the AMS usually has equipment for cleaning the teats before milking, but these cleaning devices treat every cow the same way and do not differentiate between dirty and clean udders. Once again we need to recognize that other experiments have revealed no effect on TBC or in some cases even an improvement in TBC (Salovou et al., 2005). In this case, the authors attributed the positive results to several factors, such as good maintenance of milking equipment, cleaning of the plant 3 times per day, and shorter intervals between milking, which mean bacteria have less time to multiply in the equipment.

\section{Milk Composition and Physical Aspects}

Milking robots are subjected to frequent washing and rinsing, which might be expected to affect the milk freezing point $\left({ }^{\circ} \mathrm{C}\right)$. The freezing point of cow milk is relatively constant as a consequence of the osmotic equilibrium in milk and blood. Therefore, this parameter is widely used to determine the presence of added water in bulk milk, whether this is the result of certain milking operations or a sign of adulteration for fraudulent purposes (Henno et al., 2008).

Table 3 reports the mean values $( \pm \mathrm{SD})$ of the freezing point $\left({ }^{\circ} \mathrm{C}\right)$ measured in the experimental and control bulk milks. It can be seen that no significant differences were found between milks from AMS and CMP. Moreover, no significant differences were observed in

Table 3. Influence of milking system on freezing point $\left({ }^{\circ} \mathrm{C}\right)$ of vat milk $^{1}$

\begin{tabular}{|c|c|c|}
\hline \multirow[b]{2}{*}{ Item } & \multicolumn{2}{|c|}{ Milking system ${ }^{2}$} \\
\hline & AMS & CMP \\
\hline Freezing point $\left({ }^{\circ} \mathrm{C}\right)$ & $-0.523 \pm 0.0010^{\mathrm{a}}$ & $-0.524 \pm 0.0015^{\mathrm{a}}$ \\
\hline \multicolumn{3}{|c|}{$\begin{array}{l}\text { aDifferent superscript letters within a row refer to statistically signifi- } \\
\text { cant differences (Student's } t \text {-test, } P \leq 0.05 \text { ). }\end{array}$} \\
\hline \multicolumn{3}{|c|}{$\begin{array}{l}{ }^{1} \text { Values are the arithmetic means }( \pm \overline{\mathrm{S} D}) \text { of } 9 \text { values obtained at } 3 \text { dif- } \\
\text { ferent times during the year. }\end{array}$} \\
\hline
\end{tabular}


Table 4. Freezing point $\left({ }^{\circ} \mathrm{C}\right)$ of milk from farms that used different models of automatic milking systems (AMS)

\begin{tabular}{llcccc}
\hline & & \multicolumn{4}{c}{${\text { Freezing point }\left({ }^{\circ} \mathrm{C}\right)}$} \\
\cline { 3 - 5 } Farm & AMS & Sample 1 & Sample 2 & Sample 3 & Mean \pm SD \\
\hline 1 & Lely Astronaut $^{1}$ & -0.524 & -0.523 & -0.524 & $-0.524 \pm 0.0006^{\mathrm{a}}$ \\
2 & Lely Astronaut $_{3}$ & -0.527 & -0.520 & -0.525 & $-0.524 \pm 0.0036^{\mathrm{a}}$ \\
4 & WestfaliaSurge $^{2}$ & -0.524 & -0.525 & -0.525 & $-0.525 \pm 0.0006^{\mathrm{a}}$ \\
5 & VMS, DeLaval $^{3}$ & -0.525 & -0.522 & -0.523 & $-0.523 \pm 0.0015^{\mathrm{a}}$ \\
6 & Lely Astronaut $^{\mathrm{a}}$ & -0.525 & -0.521 & -0.527 & $-0.524 \pm 0.0031^{\mathrm{a}}$ \\
7 & WestfaliaSurge & -0.520 & -0.522 & -0.524 & $-0.522 \pm 0.0020^{\mathrm{a}}$ \\
\hline
\end{tabular}

${ }^{a}$ Different superscript letters within a column refer to statistically significant differences (Tukey honestly significant difference test, $P \leq 0.05$ ).

${ }^{1}$ Lely, Bain-de-Bretagne, France.

${ }^{2}$ GEA Farm Technologies GmbH, Bönen, Germany.

${ }^{3}$ DeLaval Group, Tumba, Sweden.

freezing point between milks from different models of AMS used in the different farms considered in this study (Table 4). Finally, in all cases, the freezing point was lower than the limit value $\left(-0.520^{\circ} \mathrm{C}\right)$ established by European law (Council Directive 92/46/EEC, 1992; Council of the European Communities, 1992). It would, therefore, appear that the cleaning and rinsing cycles in AMS do not determine a significant addition of water to the milk.

Table 5 reports the mean values and standard deviations of the chemical characteristics of vat milk samples from AMS and from CMP. From data shown in the table, it was not possible to discern a statistically significant difference in fat, protein, and lactose content; in the casein index; and in the fat:protein ratio between the control and the experimental milks. These data are in agreement with those reported by Amos et al. (1985) and DePeters et al. (1985). We believe that the absence of a relationship between milking frequency and milk composition in terms of fat and protein content, which has been reported by some other authors, derives from

Table 5. Influence of milking system on chemical composition of vat milk $^{1}$

\begin{tabular}{lrr}
\hline & \multicolumn{2}{c}{ Milking system $^{2}$} \\
\cline { 2 - 3 } Item & \multicolumn{1}{c}{ AMS } & \multicolumn{1}{c}{ CMP } \\
\hline Fat $(\%)$ & $3.82 \pm 0.17^{\mathrm{a}}$ & $3.72 \pm 0.20^{\mathrm{a}}$ \\
Protein (\%) & $3.28 \pm 0.06^{\mathrm{a}}$ & $3.34 \pm 0.07^{\mathrm{a}}$ \\
Fat/protein & $1.16 \pm 0.04^{\mathrm{a}}$ & $1.11 \pm 0.06^{\mathrm{a}}$ \\
Casein index $[(\mathrm{CN} / \mathrm{TN}) \times 100]$ & $77.13 \pm 1.33^{\mathrm{a}}$ & $77.29 \pm 0.56^{\mathrm{a}}$ \\
Lactose $(\%)$ & $4.98 \pm 0.025^{\mathrm{a}}$ & $4.89 \pm 0.03^{\mathrm{a}}$ \\
\hline
\end{tabular}

${ }^{\mathrm{a}}$ Different superscript letters within a row refer to statistically significant differences (Student's $t$-test, $P \leq 0.05$ ).

${ }^{1}$ Values are the arithmetic means $( \pm \mathrm{SD})$ of 9 values obtained at 3 different times during the year. $\mathrm{TN}=$ total nitrogen.

${ }^{2} \mathrm{AMS}=$ automatic milking system; CMP $=$ conventional milking parlor. the fact that, in our case, bulk milk from several different farms was analyzed (Løvendahl and Chagunda, 2011).

When milk is used in cheese production, the casein index and the percentage ratio between the individual casein fractions affect clotting properties and can, in turn, influence the quality and yield of the cheese. The native milk protease plasmin is responsible for most of the damage to casein in milk with low bacterial counts. Milk remains in the mammary gland between milkings at $38.5^{\circ} \mathrm{C}$, the optimal temperature for proteolysis by plasmin (Politis et al., 1989). If milk is in the mammary gland for less time, then there is less time for plasmin to degrade casein. Different authors hypothesized that milking 3 times per day would increase milk quality because of the decreased time for plasmin to degrade casein in the udder at $38.5^{\circ} \mathrm{C}$ (Abeni et al., 2003). Table 6 reports the mean values $( \pm \mathrm{SD})$ of the percentage ratio of the single casein fractions in vat milk samples from AMS and from CMP. The data were calculated from the value of the HPLC peak area of the single

Table 6. Mean values $( \pm \mathrm{SD})$ of the percentage ratio of the single casein fractions in vat milk samples ${ }^{1}$

\begin{tabular}{lcc}
\hline & \multicolumn{2}{c}{ Milking system $^{2}$} \\
\cline { 2 - 3 } Casein \\
\cline { 2 - 3 } & AMS & CMP \\
\hline$\beta-C N$ & $43.38 \pm 0.86^{\mathrm{a}}$ & $44.32 \pm 1.15^{\mathrm{a}}$ \\
$\alpha-\mathrm{CN}$ & $46.31 \pm 0.56^{\mathrm{a}}$ & $45.47 \pm 1.13^{\mathrm{a}}$ \\
$\kappa-\mathrm{CN}$ & $10.31 \pm 1.00^{\mathrm{a}}$ & $10.21 \pm 0.30^{\mathrm{a}}$ \\
\hline
\end{tabular}

${ }^{a}$ Values within a row followed by the same superscript letters do not differ significantly according to the Student's $t$-test $(P>0.05)$.

${ }^{1}$ The data were calculated from the value of the HPLC peak area of the single casein fraction divided by the sum of the peak areas of all the casein fractions identified.

${ }^{2} \mathrm{AMS}=$ automatic milking system $; \mathrm{CMP}=$ conventional milking parlor. 
Table 7 . Mean values $( \pm \mathrm{SD})$ of the percentage ratio of the single whey protein fractions in vat milk samples ${ }^{1}$

\begin{tabular}{lrr}
\hline & \multicolumn{2}{c}{ Milking system $^{2}$} \\
\cline { 2 - 3 } Item & \multicolumn{1}{c}{ AMS } & \multicolumn{1}{c}{ CMP } \\
\hline$\beta$-LG & $61.68 \pm 0.85^{\mathrm{a}}$ & $61.93 \pm 1.26^{\mathrm{a}}$ \\
$\alpha$-LA & $25.78 \pm 0.85^{\mathrm{a}}$ & $25.31 \pm 1.29^{\mathrm{a}}$ \\
BSA & $6.61 \pm 0.54^{\mathrm{a}}$ & $6.82 \pm 0.44^{\mathrm{a}}$ \\
Proteose peptones & $6.51 \pm 0.65^{\mathrm{a}}$ & $5.94 \pm 0.51^{\mathrm{a}}$ \\
\hline
\end{tabular}

${ }^{a}$ Values within a row followed by the same superscript letters do not differ significantly according to the Student's $t$-test $(P>0.05)$.

${ }^{1}$ The data were calculated from the value of the HPLC peak area of the single whey protein divided by the sum of the peak areas of all the whey protein fractions identified.

${ }^{2} \mathrm{AMS}=$ automatic milking system; $\mathrm{CMP}=$ conventional milking parlor.

casein fraction divided by the sum of the peak areas of all the casein fractions identified. Statistical analysis of data showed no significant differences in the relative percentage ratio of milk casein fractions between the control and experimental milk. $\beta$-Casein is the first protein that can be attacked by the proteolytic enzyme plasmin, obtaining the production of proteose peptones and $\gamma$-CN (Dalgleish, 1992). It should be particularly emphasized that the relative percentage ratio of $\beta-\mathrm{CN}$ was similar in control and experimental milk samples. This means that the 2 milks do not display significantly different plasmin activity, in contrast to what has been suggested by some authors (Stelwagen et al., 1994; Abeni et al., 2003). This is confirmed by the profile of the individual whey protein fractions shown in Table 7. Also, in this case, data were calculated from the value of the HPLC peak area of the single whey fraction divided by the sum of the peak areas of all the whey fractions identified. It should be noted that the relative percentage ratios of proteose peptones, which are a product of proteolysis of $\beta-\mathrm{CN}$, were statistically comparable in the 2 milks. No significant differences were observed in the profiles of the other whey fractions $(\beta-\mathrm{LG}, \alpha-\mathrm{LA}$, and BSA).

Table 8 reports the means and standard deviations of the rheological characteristics of the control and ex- perimental milks. Bulk milk clotting characteristics $(r$, $a_{30}$, and $k_{20}$ ) did not differ between milk from AMS and milk from CMP. These results are in agreement with those reported by Abeni et al. (2003), even if other authors indicated that clotting features can also be affected both by the storage technology associated with AMS and the different milking frequency (Raynal and Remeuf, 2000). Independent of the milking system, all the vat milk samples analyzed presented good cheesemaking aptitude (Zannoni and Annibaldi, 1981).

\section{Cheese Composition During Aging}

In Table 9, the cheese yield performance of AMS milk was compared with that of CMP milk. As can be seen, AMS and CMP milk showed identical cheese yield efficiencies both at $24 \mathrm{~h}$ after cheese making and at $10 \mathrm{~d}$ of ripening.

In Figure 1 we reported the evolution of moisture (\%) as a function of ripening time in the control cheeses produced by AMS milk and in the experimental cheeses produced by CMP milk. Moisture gradually decreases during aging and the trends of the experimental and control cheese were similar. In addition, at $60 \mathrm{~d}$ of ripening, all cheeses had a moisture content below about $37 \%$, as required by the European Union regulation for this product (Commission Regulation EC No. 1107/1996; European Commission, 1996).

Table 10 shows the contents of fat and protein on a dry basis for different cheeses. As expected from the results of the milk analysis, no significant differences in protein and fat content were detected. Montasio cheese can clearly be considered a full-fat cheese (Codex Standard, 1999; Codex Standard A-6-1978, Rev. 1-1999).

The percentage ratio of $\mathrm{SN} / \mathrm{TN}$ was chosen as a parameter to indicate the progress of proteolysis in cheeses. Figure 2 showed the trends of this parameter as a function of ripening time. The proteolysis index increased significantly as aging increased. At all aging times considered here, the values of the SN/TN percentage ratio were comparable with those reported in the literature for this cheese (Innocente and Corradini,

Table 8. Milk clotting parameters (mean values $\pm \mathrm{SD}$ ) evaluated by a Formagraph (Foss Electric A/S, Hillerød, Denmark)

\begin{tabular}{lrr}
\hline & \multicolumn{2}{c}{ Milking system $^{1}$} \\
\cline { 2 - 3 } Parameter & AMS & CMP \\
\hline Rennet coagulation time $(r ; \mathrm{min})$ & $16.71 \pm 2.68^{\mathrm{a}}$ & $17.04 \pm 2.37^{\mathrm{a}}$ \\
Curd firmness $\left(a_{30} ; \mathrm{mm}\right)$ & $20.83 \pm 4.24^{\mathrm{a}}$ & $21.18 \pm 5.33^{\mathrm{a}}$ \\
Time to curd firmness of $20 \mathrm{~mm}\left(k_{20} ; \mathrm{min}\right)$ & $7.51 \pm 0.50^{\mathrm{a}}$ & $6.99 \pm 0.90^{\mathrm{a}}$ \\
\hline${ }^{\mathrm{a}}$ Values within a row followed by the same superscript letters do not differ significantly according to the \\
Student's $t$-test $(P>0.05)$.
\end{tabular}


Table 9. Yield $(\mathrm{kg} ; \pm \mathrm{SD})$ of cheeses from automatic milking system (AMS) and conventional milking parlor (CMP) milks

\begin{tabular}{|c|c|c|}
\hline \multirow[b]{2}{*}{ Yield } & \multicolumn{2}{|c|}{ Milking system } \\
\hline & AMS & CMP \\
\hline $\begin{array}{l}\text { Yield at } 24 \mathrm{~h} \\
\text { Yield at } 10 \mathrm{~d}\end{array}$ & $\begin{aligned} 10.40 & \pm 0.11^{\mathrm{a}} \\
8.82 & \pm 0.10^{\mathrm{a}}\end{aligned}$ & $\begin{aligned} 10.52 & \pm 0.14^{\mathrm{a}} \\
9.06 & \pm 0.16^{\mathrm{a}}\end{aligned}$ \\
\hline
\end{tabular}

${ }^{\mathrm{a}}$ Values within a row followed by the same superscript letters do not differ significantly according to the Student's $t$-test $(P>0.05)$.

1996; Innocente, 1997). The milking system did not significantly influence proteolysis progress during the aging process. This is an important result if we consider that for hard and semi-hard cheeses, regular proteolysis evolution is a prerequisite for good flavor development. In fact, the first level of proteolysis results from enzymatic action on curdled milk and the consequent release of casein-derived peptides and amino acids. Later, these amino acids are further broken down by enzymes involved in deamination, decarboxylation, transamination, or demethiolation (or all of these; Hemme et al., 1982). These reactions may lead to the development of important and specific flavors (Griffith and Hammond, 1989). In the case of Montasio cheese, the principal enzymatic activities that are responsible for proteolysis are the native plasmin protease and the microbial protease of thermophilic culture inoculated with starters. In fact, plasmin is a thermoresistant enzyme that remains active even after the curd cooking process. Indeed, according to some authors, an increase in the activity of this enzyme occurs in the cooked curd because the heat treatment activates plasminogen (Farkye and Fox, 1990). Regarding microbial activity, on the other hand, the processing conditions of this cheese promote the development of mesophilic and thermophilic microbial lactic flora with proteolytic activity (Marino et al., 2003; Carraro et al., 2011). Therefore, we can affirm that the cheeses made with AMS milk and CMP milk do not display significantly different plasmin activity or microbial lactic microflora activity.

Table 10. Influence of milking system on fat and protein content of cheeses from automatic milking system (AMS) and conventional milking parlor $(\mathrm{CMP})$ milks $^{1}$

\begin{tabular}{lcc}
\hline \multirow{2}{*}{ Item } & \multicolumn{2}{c}{ Milking system } \\
\cline { 2 - 3 } & AMS & CMP \\
\hline Fat $(\mathrm{g} / 100$ g of DM) & $51.55 \pm 0.80^{\mathrm{a}}$ & $52.15 \pm 0.64^{\mathrm{a}}$ \\
Protein $(\mathrm{g} / 100 \mathrm{~g}$ of $\mathrm{DM})$ & $38.63 \pm 0.46^{\mathrm{a}}$ & $38.20 \pm 0.41^{\mathrm{a}}$ \\
\hline
\end{tabular}

${ }^{\mathrm{a}}$ Values within a row followed by the same superscript letters do not differ significantly according to the Student's $t$-test $(P>0.05)$.

${ }^{1}$ Values are the arithmetic means $( \pm \mathrm{SD})$ of 9 values obtained at 3 different times during the year.

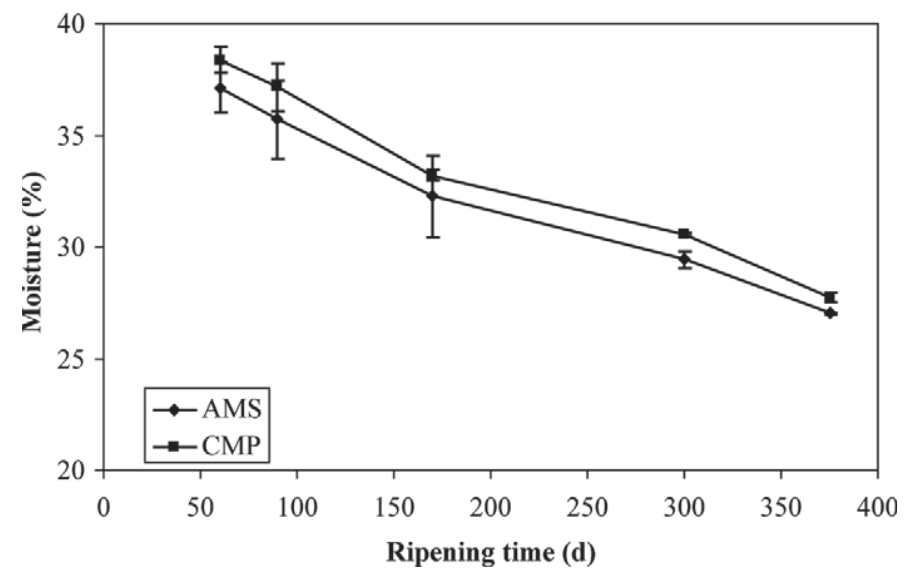

Figure 1. Trend of moisture content (\%) during ripening of cheeses from automatic milking system (AMS) and conventional milking parlor (CMP) milks. Error bars indicate standard deviations.

The volatile profile is generally recognized as one of the most important criteria for evaluating cheese quality. It reflects the image of the odor and aroma of cheese and is recognized as being useful both in characterizing the cheese and in defining its ties with the area and methodology of production (Gioacchini et al., 2010). In fact, the volatile profile can be considered as a fingerprint, as the flavor of a cheese variety is the result of a specific balance between the volatile compounds produced during the ripening process (McSweeney and Sousa, 2000; Rehman et al., 2000).

Figure 3 shows the evolution of the total volatile fraction profile, expressed as an average value of the sum of the absolute areas of the peaks measured in the headspace of the Montasio cheese samples during ripening. It can be seen that the total volatile profile

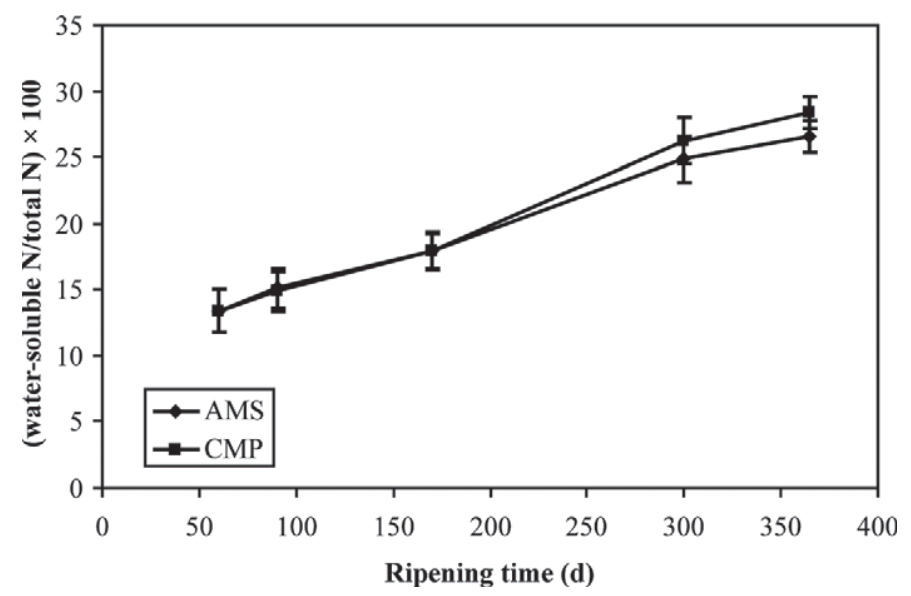

Figure 2. Trend of water-soluble $\mathrm{N} /$ total $\mathrm{N}$ ratio during ripening of cheeses from automatic milking system (AMS) and conventional milking parlor (CMP) milks. Error bars indicate standard deviations. 
Table 11. Volatile compounds identified by solid-phase microextraction (SPME)-GC-MS analysis in the headspace of the Montasio cheese samples

\begin{tabular}{lclr}
\hline No. & $\mathrm{RT}^{1}$ & Compound $^{2}$ & $\begin{array}{c}\text { Observed Kovats } \\
\text { retention index }\end{array}$ \\
\hline 1 & 2.21 & Ethanol & 961 \\
2 & 2.58 & 2,3-Butanedione & 1011 \\
3 & 4.33 & 3-Methyl-1-butanol & 1167 \\
4 & 4.78 & Ethyl hexanoate & 1190 \\
5 & 6.80 & 3-Hydroxy-2-butanone & 1282 \\
6 & 9.68 & Acetic acid & 1432 \\
7 & 11.89 & 2,3-Butanediol & 1584 \\
8 & 12.09 & Butanoic acid & 1598 \\
9 & 14.65 & Hexanoic acid & 1822 \\
10 & 16.81 & Octanoic acid & 2037 \\
11 & 18.72 & Decanoic acid & 2247 \\
${ }^{1}$ Retention time (min). & & \\
${ }^{2}$ Identification was performed by comparison of mass spectra and retention time with those of standard com- \\
pounds.
\end{tabular}

of the cheeses progressively increased from 60 to 170 d, after which time it remained almost steady. No evidence existed that the milking process influences the total volatile profile of cheese: at all ripening times considered, experimental and control cheeses displayed similar levels of total volatile compounds.

Overall, in the headspace of the Montasio cheese samples, a total of 11 compounds were identified (namely 5 FA, 3 alcohols, 2 ketones, and 1 ester). Table 11 lists all the components identified in Montasio cheeses.

Table 12 shows the mean values of the sum of the absolute peak areas of the volatile compounds, grouped according to chemical class (alcohols, ketones, FA, and esters). It can be seen that alcohols and FFA were the compounds present in higher quantities in the head-

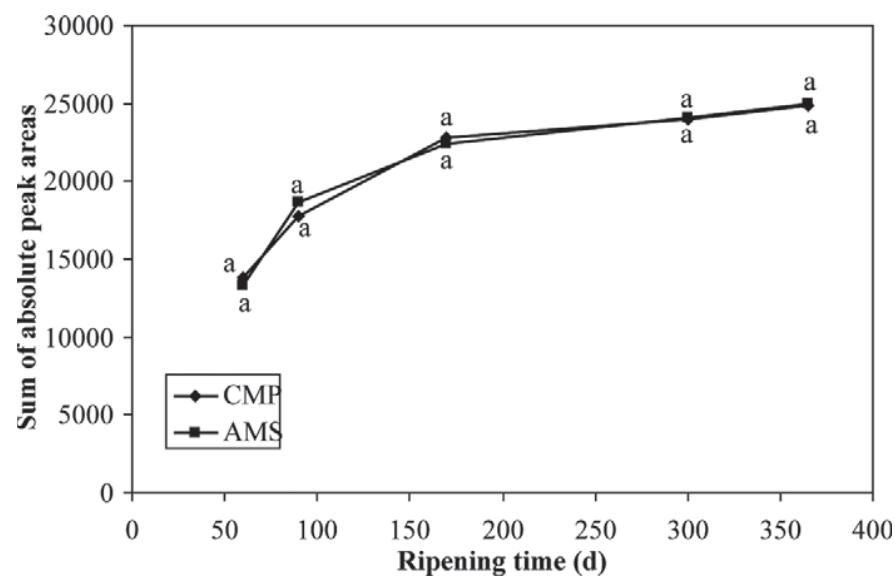

Figure 3. Total volatile profile, expressed as the mean value of the sum of the absolute areas measured in the headspace of the Montasio cheese samples during ripening. In the graph, mean values with different letters differ statistically at $P \leq 0.05$ according to the Student's $t$-test. $\mathrm{CMP}=$ conventional milking parlor; $\mathrm{AMS}=$ automatic milking system. space of the all Montasio cheese samples analyzed. The alcohols identified in the Montasio samples have also been found in other cheeses and are generally responsible for the presence of floral and alcoholic aromatic notes (Molimard and Spinnler, 1996; Curioni and Bosset, 2002). Due to their low perception thresholds, short- and medium-chain, even-numbered $\left(\mathrm{C}_{4}\right.$ to $\left.\mathrm{C}_{12}\right)$ FA are also reported to play an important role in the flavor profile of a wide variety of cheeses (Molimard and Spinnler, 1996; Curioni and Bosset, 2002). Ketones and esters are present in lesser amounts in Montasio cheese, but certainly contribute to the flavor profile of this cheese. For example, ketones are well known for conferring buttery notes to cheese, whereas ester compounds are reported to have fruity notes (Molimard and Spinnler, 1996; Moio and Addeo, 1998; Curioni and Bosset, 2002).

As expected, significant changes in the volatile profile occurred over the ripening period: alcohols and FA increased up to $170 \mathrm{~d}$ and then they remained almost steady; ketones increased up to $170 \mathrm{~d}$ and then they tended to decrease; esters progressively increased to the end of the ripening period. These behaviors were in accord with those reported in previous studies (N. Innocente, unpublished data) and were similar for AMS and CMP cheeses.

The descriptive sensory analysis was then applied to allow qualitative and quantitative measurements of sensory properties of Montasio cheeses. The sensory profile of cheeses from AMS and CMP milks at $90 \mathrm{~d}$ of ripening was obtained using the spider-plot representation in Figure 4 . As can be seen, the 2 profiles were similar to each other and no significant differences were observed in any of the sensory descriptors considered. The same consideration can be made for the sensory profiles at $60,170,300$, and $365 \mathrm{~d}$ of ripening (data not shown). 
Table 12. Sum of the absolute peak areas of the volatile compounds, grouped according to chemical class, measured in the Montasio cheese samples during ripening ${ }^{1}$

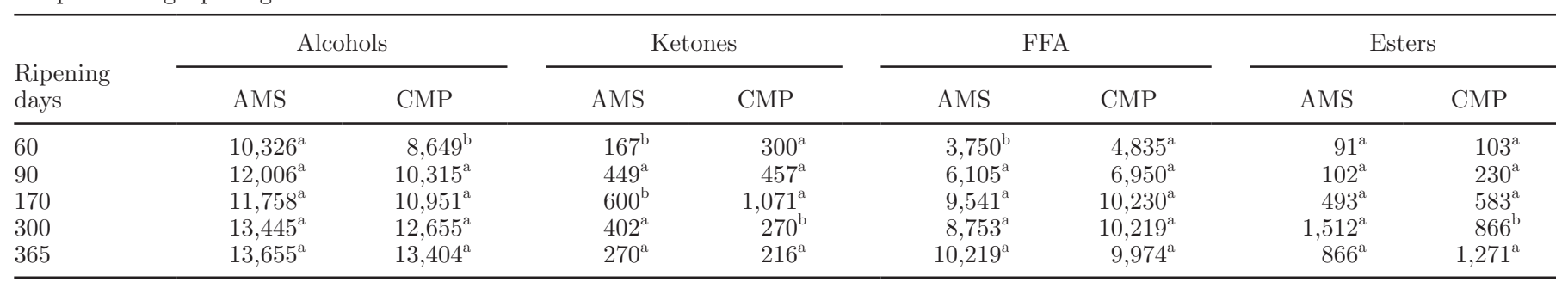

$\overline{\mathrm{a}, \mathrm{b}}$ Values within a row followed by the same superscript letters do not differ significantly according to the Student's $t$-test $(P>0.05)$.

${ }^{1}$ Values are the arithmetic means of 9 values obtained at 3 different times during the year. AMS $=$ automatic milking system; CMP $=$ conventional milking parlor.

Moreover, both the profiles considered fall within the confidence interval, which defines the sensory profile typical of this cheese (N. Innocente, unpublished data).

\section{CONCLUSIONS}

In general, we can conclude that, from the microbiological, physicochemical, and rheological results obtained, in our experimental conditions, bulk AMS and CMP milk samples did not display significant differences as a result of the milking process. In fact, no evidence was found of significant differences in SCC and TBC, freezing point, fat and protein contents, and clotting characteristics. Finally, the cheeses obtained from ASM milk and CMP milk had the same composition characteristics and did not differ with regard to their aromatic and the sensory profiles. The milking system did not significantly influence proteolysis progress during the aging process. Based on these results, we believe

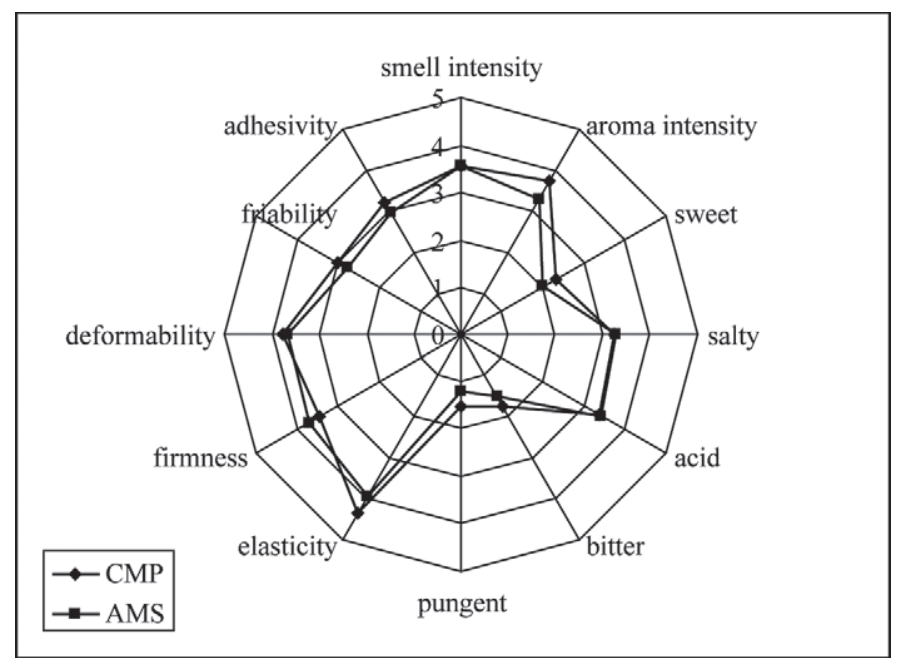

Figure 4. Sensory profile of Montasio cheese from automatic milking system (AMP) and conventional milking parlor (CMP) milks at $90 \mathrm{~d}$ of ripening. that AMS can be used in the Montasio cheese production chain without significantly modifying the typical characteristics of the cheese.

\section{REFERENCES}

Abeni, F., L. Degano, R. Giangiacomo, M. Speroni, and G. Pirlo. 2003. Robotic milking and milk quality: Effects on the cheese making properties of milk. Ital. J. Anim. Sci. 2:301-312.

Abeni, F., M. G. Terzano, M. Speroni, L. Migliorati, M. Cappelletti, F. Calza, L. Bianchi, and G. Pirlo. 2008. Evaluation of milk enzymes and electrolytes, plasma metabolites, and oxidative status in twin cows milked in an automatic milking system or twice daily in a conventional milking parlor. J. Dairy Sci. 91:3372-3384.

Albenzio, M., M. Caroprese, A. Santillo, R. Marini, L. Taibi, and A. Sevi. 2004. Effect of somatic cell count and stage of lactation on plasmin activity and cheese-making properties of ewe milk. J. Dairy Sci. 87:533-542.

Allen, D. B., E. J. DePeters, and R. C. Laben. 1986. Three times a day milking: Effects on milk production, reproductive efficiency, and udder health. J. Dairy Sci. 69:1441-1446.

Amos, H. E., T. Kiser, and M. Loewenstein. 1985. Influence of milking frequency on productive and reproductive efficiencies of dairy cows. J. Dairy Sci. 68:732-739.

Barbano, D. M., J. L. Clark, C. E. Dunham, and J. R. Fleming. 1990. Kjeldahl method for determination of total nitrogen content of milk: Collaborative study. J. Assoc. Off. Anal. Chem. 73:849-859.

Berglund, I., K. Pettersson, and K. Svennersten-Sjaunja. 2002. Automatic milking: Effects on somatic cell count and teat end-quality. Livest. Prod. Sci. 78:115-124.

Bérodier, F., P. Lavanchy, M. Zannoni, J. Casals, L. Herrero, and C. Adamo. 1997. A guide to the sensory evaluation of smell, aroma and taste of hard and semi-hard cheeses. Lebensm. Wiss. Technol. 30:653-664.

Biasutti, M., and N. Innocente. 2006. Effect of a post-processing phase on the volatile flavour compounds of Asino cheese. Ital. J. Food Sci. 18:1-13.

Bobe, G., D. C. Beitz, A. E. Freeman, and G. L. Lindberg. 1998. Separation and quantification of bovine milk proteins by reversedphase high-performance liquid chromatography. J. Agric. Food Chem. 46:458-463.

Carraro, L., M. Maifreni, I. Bartolomeoli, M. E. Martino, E. Novelli, F. Frigo, M. Marino, and B. Cardazzo. 2011. Comparison of culture-dependent and -independent methods for bacterial community monitoring during Montasio cheese manufacturing. Res. Microbiol. 162:231-239.

Codex Standard. 1999. Codex general standard for cheese. Codex Standard A-6-1978, Rev. 1-1999. Codex Alimentarius Commission, Rome, Italy.

Council of the European Communities. 1992. Council Directive 92/46/ EEC laying down the health rules for the production and placing 
on the market of raw milk, heat-treated milk and milk-based products. Official Journal of the European Union, L 228:1-23.

Curioni, P. M. G., and J. O. Bosset. 2002. Key odorants in various cheese types as determined by gas chromatography-olfactometry. Int. Dairy J. 12:959-984.

Dalgleish, D. G. 1992. Bovine milk protein properties and the manufacturing quality of milk. Livest. Prod. Sci. 35:75-93.

De Noni, I., L. Pellegrino, S. Cattaneo, and P. Resmini. 2007. HPLC of proteose peptones for evaluating ageing of packaged pasteurized milk. Int. Dairy J. 17:12-19.

DePeters, E. J., N. E. Smith, and J. Acedo-Rico. 1985. Three or two times daily milking of older cows and first lactation cows for entire lactations. J. Dairy Sci. 68:123-132.

Downey, W. K. 1980. Review of the progress of dairy science: Flavour impairment from pre- and post-manufacture lipolysis in milk and dairy products. J. Dairy Res. 47:237-252.

European Commission. 1996. On the registration of geographical indications and designations of origin under the procedure laid down in Article 17 of Council Regulation (EEC) No 2081/92. Commission Regulation (EC) No. 1107. Official Journal of the European Union, L 148:1-24.

European Commission. 2004. Regulation EC No 853/2004 of the European Parliament and of the Council laying down specific hygiene rules for on the hygiene of foodstuffs. Official Journal of the European Union L 139/55.

European Commission. 2006. On the protection of geographical indications and designation of origin for agricultural products and foodstuffs. Council Regulation EC No. 510. Official Journal of the European Union, L 93:12-20.

EVS-EN ISO (Estonian Center for Standardization). 2002. Milk determination of freezing point. Thermistor cryoscope method. EVSEN ISO 5764. Eesti Standardiamet, Tallinn, Estonia.

Farkye, N. Y., and P. F. Fox. 1990. Observation on plasmin activity in cheese. J. Dairy Res. 57:413-418.

Friggens, N. C., and M. D. Rasmussen. 2001. Milk quality assessment in automatic milking systems: Accounting for the effects of variable intervals between milkings on milk composition. Livest. Prod. Sci. $73: 45-54$

Gioacchini, A. M., M. De Santi, M. Guescini, G. Brandi, and V. Stocchi. 2010. Characterization of the volatile organic compounds of Italian 'Fossa' cheese by solid-phase microextraction gas chromatography/mass spectrometry. Rapid Commun. Mass Spectrom. 24:3405-3412.

Griffith, R., and E. G. Hammond. 1989. Generation of Swiss cheese flavor components by the reaction of amino acids with carbonyl compounds. J. Dairy Sci. 72:604-613.

Hemme, D., C. Bouillanne, F. Métro, and M. J. Desmazeaud. 1982. Microbial catabolism of amino acids during cheese ripening. Sci. Aliments 2:113-123.

Henno, M., M. Ots, I. Jõudu, T. Kaart, and O. Kärt. 2008. Factors affecting the freezing point stability of milk from individual cows. Int. Dairy J. 18:210-215.

Innocente, N. 1997. Free amino acids and water soluble nitrogen as ripening indices in Montasio cheese. Lait 77:359-369.

Innocente, N., and C. Corradini. 1996. Effect of ripening temperature on the maturation of Montasio cheese. Ital. J. Food Sci. 4:291-302.

IDF (International Dairy Federation). 1964a. Determination of the casein content of milk. IDF Standard No. 29. IDF, Brussels, Belgium.

IDF (International Dairy Federation). 1964b. Determination of the protein content of processed cheeses products IDF Standard No. 25. IDF, Brussels, Belgium.

IDF (International Dairy Federation). 1982. Cheese and processed cheese. Determination of the total solid content. IDF Standard No 4A. IDF, Brussels, Belgium.

IDF (International Dairy Federation). 1986. Cheese and processed cheese. Determination of the fat content. IDF Standard No. 5B. IDF, Brussels, Belgium.

IDF (International Dairy Federation). 1996 Determination of fat content of milk. IDF Standard No. 1D. IDF, Brussels, Belgium.
Jeon, I. J., S. J. Galitzer, and K. J. Hennessy. 1984. Rapid determination of lactose and its hydrolyzates in whey and whey permeate by high performance liquid chromatography. J. Dairy Sci. 67:884-887.

Kaartinen, L., T. Ali-Vehmas, and M. Sandholm. 1990. Effect of frequent milkings on milk NAGase, plasmin, trypsin inhibitory capacity and the quality of whey as the growth medium for mastitis pathogens. Zentralbl. Veterinarmed. B 37:337-344.

Kelly, A. L., and P. L. H. McSweeney. 2002. Indigenous proteinases in milk. Pages 494-519 in Advanced Dairy Chemistry, Vol. 1, Part B. P. F. Fox, P. L. H. McSweeney, ed. Kluwer Academic Publishers, New York, NY.

Klei, L. R., J. M. Lynch, D. M. Barbano, P. A. Oltenacu, A. J. Lednor, and D. K. Bandler. 1997. Influence of milking three times a day on milk quality. J. Dairy Sci. 80:427-436.

Klungel, G. H., B. A. Slaghuis, and H. Hogeveen. 2000. The effect of the introduction of automatic milking systems on milk quality. J. Dairy Sci. 83:1998-2003.

Knight, C. H., M. Peaker, and C. J. Wilde. 1998. Local control of mammary development and function. Rev. Reprod. 3:104-112.

Lavanchy, P., F. Bérodier, M. Zannoni, Y. Noel, C. Adamo, J. Squella, and L. Herrero. 1993. Sensory evaluation of the texture of hard and semi-hard cheeses. Lebensm. Wiss. Technol. 26:59-68.

Løvendahl, P., and M. G. G. Chagunda. 2011. Covariance among milking frequency, milk yield, and milk composition from automatically milked cows. J. Dairy Sci. 94:5381-5392.

Marino, M., M. Maifreni, and G. Rondinini. 2003. Microbiological characterization of artisanal Montasio cheese: Analysis of its indigenous lactic acid bacteria. FEMS Microbiol. Lett. 229:133-140.

McMahon, D. J., and R. J. Brown. 1982. Evaluation of Formagraph for comparing rennet solutions. J. Dairy Sci. 65:1639-1642.

McSweeney, P. L. H., and M. J. Sousa. 2000. Biochemical pathways for the production of flavour compounds in cheeses during ripening: A review. Lait 80:293-324.

Moio, L., and F. Addeo. 1998. Grana Padano cheese aroma. J. Dairy Res. 65:317-333

Molimard, P., and H. E. Spinnler. 1996. Review: Compounds involved in the flavor of surface mold-ripened cheeses: Origins and properties. J. Dairy Sci. 79:169-184.

Mollenhorst, H., M. M. Hidayat, J. van den Broek, F. Neijenhuis, and H. Hogeveen. 2011. The relationship between milking interval and somatic cell count in automatic milking systems. J. Dairy Sci. 94:4531-4537.

Neijenhuis, F., G. H. Klungel, and H. Hogeveen. 2001. Recovery of cow teats after milking as determined by ultrasonographic scanning. J. Dairy Sci. 84:2599-2606.

Nielsen, N. I., T. Larsen, M. Bjerring, and L. Ingvartsen. 2005. Quarter health, milking interval, and sampling time during milking affect the concentration of milk constituents. J. Dairy Sci. 88:31863200 .

O'Brien, B., W. J. Meaney, D. McDonagh, and A. Kelly. 2001. Influence of somatic cell count and storage interval on composition and processing characteristics of milk from cows in late lactation. Aust. J. Dairy Technol. 56:213-218.

Österman, S., K. Östensson, K. Svennersten-Sjaunja, and J. Bertilsson. 2005. How does extended lactation in combination with different milking frequencies affect somatic cell count in dairy cows? Livest. Prod. Sci. 96:225-232.

Ouweltjes, W. 1998. The relationship between milk yield and milking interval in dairy cows. Livest. Prod. Sci. 56:193-201.

Politis, I., K. F. Ng Kwai Hang, and R. N. Giroux. 1989. Environmental factors affecting plasmin activity in milk. J. Dairy Sci. 72:1713-1718.

Rasmussen, M. D., M. Bjerring, P. Justesen, and L. Jepsen. 2002. Milk quality on Danish farms with automatic milking systems. J. Dairy Sci. 85:2869-2878.

Raynal, K., and F. Remeuf. 2000. Effect of storage at $4^{\circ} \mathrm{C}$ on the physicochemical and renneting properties of milk: A comparison of caprine, ovine and bovine milks. J. Dairy Res. 67:199-207.

Rehman, S.-U., J. M. Banks, E. Y. Brechany, D. D. Muir, P. L. H. McSweeney, and P. F. Fox. 2000. Influence of ripening temperature 
on the volatile profile and flavour of Cheddar cheese made from raw or pasteurised milk. Int. Dairy J. 10:55-65.

Salovou, H., P. Ronkainen, A. Heino, A. Suokannas, and E.-L. Ryhänen. 2005. Introduction of automatic milking system in Finland: Effect on milk quality. Agric. Food Sci. 14:346-353.

Sapru, A., D. M. Barbano, J. J. Yun, L. R. Klei, P. A. Oltenacu, and D. K. Bandler. 1997. Cheddar cheese: Influence of milking frequency and stage of lactation on composition and yield. J. Dairy Sci. 80:437-446.

Smith, J. W., L. O. Ely, W. M. Graves, and W. D. Gilson. 2002. Effect of milking frequency on DHI performance measures. J. Dairy Sci. 85:3526-3533.

Sorensen, A., D. D. Muir, and C. H. Knight. 2001. Thrice-daily milking throughout lactation maintains epithelial integrity and thereby improves milk protein quality. J. Dairy Res. 68:15-25.
Sørhaug, T., and L. Stepaniak. 1997. Psychrotrophs and their enzymes in milk and dairy products: Quality aspects. Trends Food Sci. Technol. 8:35-40.

Stelwagen, K., I. Politis, J. H. White, B. Zavizion, C. G. Prosser, S. R. Davis, and V. C. Farr. 1994. Effect of milking frequency and somatotropin on the activity of plasminogen activator, plasminogen, and plasmin in bovine milk. J. Dairy Sci. 77:3577-3583.

Svennersten-Sjaunja, K. M., and G. Pettersson. 2008. Pros and cons of automatic milking in Europe. J. Anim. Sci. 86(Suppl. 1):37-46.

Zannoni, M., and S. Annibaldi. 1981. Standardization of the renneting ability of milk by Formagraph. Scienza e Tecnica Lattiero Casearia 32:79-94. 